\title{
Sedimentary evidence of extreme storm surge or tsunami events in the southern Baltic Sea (Rogowo area, NW Poland)
}

\author{
Andrzej PIOTROWSKII, *, Witold SZCZUCIŃSKI ${ }^{2}$, Paweł SYDOR ${ }^{1}$, Bartosz KOTRYS ${ }^{1}$, \\ Monika RZODKIEWICZ ${ }^{3}$ and Jarmila KRZYMIŃSKA ${ }^{4}$ \\ 1 Polish Geological Institute - National Research Institute, Pomeranian Branch, Wieniawskiego 20, \\ 71-130 Szczecin, Poland \\ 2 Adam Mickiewicz University in Poznań, Institute of Geology, Bogumiła Krygowskiego 12, 61-680 Poznań, Poland \\ 3 Adam Mickiewicz University in Poznań, Institute of Geoecology and Geoinformation, Bogumiła Krygowskiego 10, Poznań \\ 61-680, Poland \\ 4 Polish Geological Institute - National Research Institute, Marine Geology Branch, Kościerska 5, 80-328 Gdańsk, Poland
}

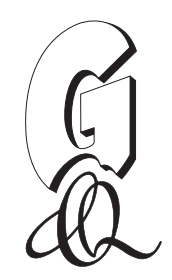

Piotrowski, A., Szczuciński, W., Sydor, P., Kotrys, B., Rzodkiewicz, M., Krzymińska, J., 2017. Sedimentary evidence of extreme storm surge or tsunami events in the southern Baltic Sea (Rogowo area, NW Poland). Geological Quarterly, 61 (4): 973-986, doi: 10.7306/gq.1385

The Baltic Sea is not typically considered as an area affected by tsunamis. However, during the Late Pleistocene and Holocene several tsunami events have been interpreted from the sedimentary record, mainly in Sweden and Estonia. Furthermore, on the southern coast of the Baltic Sea, there are historical accounts of catastrophical marine floodings called "der Seebär" ("the Sea Bear"). Their descriptions reveal many features typical for tsunami, but their genesis remained unknown and sedimentary evidence for such events has not been found. Here we provide evidence of sandy event layers from the area of Rogowo, NW Poland - the area of historical catastrophic storms as well as "der Seebär" events. The study area is a low-lying coastal plain with an average elevation of -0.5 to $+0.5 \mathrm{~m}$ a.s.l., protected from the open sea by beach and coastal dune systems up to $5 \mathrm{~m}$ high. Sedimentological, micropalaeontological and geochemical analyses along with $\mathrm{AMS}{ }^{14} \mathrm{C}$ dating were applied to sedimentary successions seen in 5 major trenches and 198 sediment cores up to $1.5 \mathrm{~m}$ long. Two sandy layers were identified in the peat deposits that developed on the plain during the last $\sim 2000$ years. They reveal a number of typical features of tsunami deposits (significant lateral extent and thickness, rip-up clasts, chemical and micropalaeontological evidence of marine origin), however, ${ }^{14} \mathrm{C}$ dating along with the historical accounts revealed that the major layer, extending at least $1.2 \mathrm{~km}$ from the modern coasts, was probably deposited by arguably the largest storm surge during the last 2000 years, which took place in 1497 AD. These storm deposits were likely formed during inundation of the low-lying coastal plain after major breaching of coastal dunes resulting in tsunami - like flow pattern and thus similar sedimentological effects. A discontinuous sand layer of younger age (18th century) and sharing similar properties to the previous one may be related to "der Seebär" event or another storm surge. The study revealed that the southern Baltic Sea coast may be affected by much greater coastal flooding than known from more recent accounts and observations. Thus, the presented geological record should be taken as an example of a worst-case scenario in coastal zone risk assessment from natural hazards. These events left sedimentary deposits that resemble tsunami deposits. It is likely that, in similar settings where storm surges cause unidirectional inundation of a coastal plain, it may not be possible to establish whether the resulting deposits were laid down from storms or tsunamis.

Key words: tsunami deposits, storm surge deposits, grain size analysis, geochemistry, radiocarbon dating, Baltic Sea.

\section{INTRODUCTION}

Catastrophic marine floodings (storms, hurricanes, tsunamis) may cause dramatic disasters as exemplified by a number of recent catastrophic events (e.g., the 2004 Indian Ocean tsunami; Hurricane Catherina in 2005; the 2011 Tohoku-oki tsunami). Many of these appeared to be unexpected since no his-

\footnotetext{
* Corresponding author, e-mail: andrzej.piotrowski@pgi.gov.pl Received: December 19, 2017; accepted August 30, 2017; first published online: September 26, 2017
}

torical records existed of events of similar size, or existing records were of limited accuracy and were not taken into account in coastal hazard assessments. Study of palaeotsunami and palaeostorm deposits in coastal sedimentary archives may provide crucial information on the occurrence and minimum magnitude of such events in the past (e.g., Jankaew et al., 2008; Goto et al., 2010, 2014).

However, at the same time it was found that both tsunami and storm deposits are source-dependent and exhibit large variability and their distinction may be difficult. They can be identified using multiple proxy criteria interpreted in the local context of sedimentary facies. Some diagnostic criteria have been developed by studying recent and past catastrophic events (e.g., Morton et al., 2007; Shiki et al., 2008; Bourgeois, 
2009; Chagué-Goff, 2010; Peters and Jaffe, 2010; Chagué-Goff et al., 2011, 2017; Goff et al., 2012; Szczuciński et al., $2012 b)$. However, there is no easy way to discriminate tsunami from storm deposits (Andrade, 1992; Nanayama et al., 2000; Goff et al., 2004; Luque et al., 2004; Tuttle et al., 2004; Dominay-Howes et al., 2006; Kortekass and Dawson, 2007; Morton et al., 2007; Switzer, 2008; Switzer and Jones, 2008; Lario et al., 2010).

Although the low-seismicity Baltic Sea setting is not considered to be typical for tsunami generation, reports from the northern shores (Mörner, 1995, 1996, 1999, 2003, 2008, 2013; Nikonov, 2004; Mörner and Dawson, 2011) provide information on a number of the past tsunami-like events. Recently, Rotnicki et al. (2016) discussed the possible tsunami origin of an event layer found in the middle part of southern Baltic Sea coastline, which was dated at $\sim 6 \mathrm{ka}$, while recent reports from Finland provide information on "meteotsunami" phenomena (Pellikka et al., 2014). Atypical marine inundations of unspecified origin have been also known from the western part of the Baltic Sea and the North Sea (e.g., Credner, 1889). The latter is related to historical accounts of "der Seebär" ("the Sea Bear") (Piotrowski, 2007a, b). Moreover, storms in the Baltic Sea have been discussed by many authors (Majewski, 1986, 1989, 1998a, b; Stigge, 1994; Dziadziuszko and Jednorał, 1996; Hupfer et al., 2003; Suursaar et al., 2003, 2006; Averkiev and Klevannyy, 2007, 2010; Gurwell, 2008; Jensen and Müller-Navarra, 2008; Rosenhagen and Bork, 2009; Wiśniewski and Wolski, 2009; Richter et al., 2012; Wolski et al., 2014). In most of the accounts storm deposits were described as washover fans with a lateral range limited to a few tens of metres (e.g., Rudowski and Wróblewski, 2000). However, some historical accounts described much more extensive inundations.

The present study focuses on geological evidences of tsunami-like events and storms on a low-lying (at sea level) coastal plain protected by a low coastal dune belt in the Rogowo area, southern Baltic Sea coast (Fig. 1). The major goals are to verify historical accounts of extraordinary catastrophic floodings in the past to provide better coastal hazard assessment, as well as to contribute to discussion of the sedimentological characteristics of tsunami and storm deposits.

\section{STUDY AREA}

The Baltic Sea is a shallow (55 m on average) semi-enclosed marginal sea. It is composed of several sills and basins. Consequently, water exchange between various parts, and between the Baltic and the North Sea, is limited. This makes the Baltic Sea the largest brackish-water basin in the world. It is considered a non-tidal sea, since the amplitude of tides rarely exceeds a few centimetres (Medvedev et al., 2013). Currently the Baltic Sea drainage area is populated by $\sim 85$ million people from 14 countries and the exploitation of Baltic Sea resources causes many conflicts between socio-economic interests and the unique ecological environment.

The Polish coast is located in the southern Baltic and has a total length of $\sim 500 \mathrm{~km}$. It is built of Quaternary glacial and glaciofluvial deposits, and modern coastal deposits. Approximately $80 \%$ of the coastline is composed of sandy beaches and dunes, while the rest is a cliff coast. Most of the coastline is not affected by engineering structures. Many low-lying parts of the shoreline are exposed to flooding caused by storm surges, which result from a combination of high wind velocity, deep low-pressure systems and thus a higher water level in the sea.
In the study area (Fig. 1) the morphology is dominated by a large flat valley (the Old Rega River Valley) formed by glacial meltwaters functioning at the end of the Late Vistulian (Pleistocene). The valley is filled with Holocene deposits (mostly peat and gyttja). Below the layer of peat are grey medium-grained sands and dark grey sands with organic matter of fluvial origin (Dobracka, 1990, 1992; Cedro, 2012). The Old Rega River Valley floor lies at a height of $0.2-0.5 \mathrm{~m}$ a.s.l. The valley is separated from the sea by a belt of coastal dunes (with heights of up to $5 \mathrm{~m}$ in the eastern part and up to $17 \mathrm{~m}$ in the western part) and also by inland dunes in the western part at heights of up to $31 \mathrm{~m}$. The dune belt protects the low-lying plain from marine flooding. The rate of coastal retreat in this region is $0.5-0.8 \mathrm{~m} / \mathrm{y}$. The width of the beach in the study area is $40-50 \mathrm{~m}$ (Dobracki and Zachowicz, 1997).

At the mouth of modern Rega River marine inflows are observed during storm surges. The current Rega mouth was artificially formed in 1457 AD (Riemann, 1873; Stoewer, 1897). Along with this investment an embankment road was made connecting the new port and fishing village of Treptowschen Tip with Trzebiatów, a city located $10 \mathrm{~km}$ south of the sea.

Historical accounts report at least two catastrophic marine inundation events in this area. The first event occurred along most of the southern Baltic Sea coast and took place on 17th of September 1497. It caused breaching of the Resko Przymorskie Lake barrier (Fig. 1), as well as coastal flooding reported in areas a few tens of $\mathrm{km}$ eastwards to reach up to $4 \mathrm{~km}$ inland. Kaliningrad (Königsberg) and Gdańsk (Danzig) were flooded, moreover Darłowo (Rügenwalde), Szczecin (Stettin), Kołobrzeg (Kolberg), Stralsund, Wismar and other coastal towns at the Baltic Sea were at least partly damaged (Riemann, 1873; Stoewer, 1897).

The second event occurred on the 3th April 1757. Brüggemann (1779) reported it as follows: "That happened on the 3rd of April, 1757 about noon, in calm and bright weather, the Baltic coast near Trzebiatów on Rega River suddenly was rolling so much that a ship, moored in the harbor, was snatched away by high waves and shifted far on to the land. After that (rolling) was repeated three times, the sea became calm again. Local people call this phenomenon the Seebär". Trzebiatów is a town located $10 \mathrm{~km}$ away from the Baltic coast. The description of this event from the mid-18th century is very similar to modern reports of tsunamis of earthquake or landslide origin.

\section{MATERIALS AND METHODS}

\section{FIELDWORK}

Fieldwork followed detailed analysis of existing data, including historical maps and notes. The key study sites identified (Fig. 1) were visited several times. The present study included documentation based on 4 major trenches and 198 boreholes up to $1.5 \mathrm{~m}$ deep (Fig. 1). Samples for further analyses were collected from trenches and boreholes, as well as from the modern beach and dunes.

\section{LABORATORY ANALYSIS}

Grain size analysis. Altogether 115 samples taken from the modern beach and dunes, as well as from event deposits collected in transects A, B and C (Fig. 1); they were dried and sieved on a Fritsch Vibratory Sieve Shaker Analysette 3 PRO. 

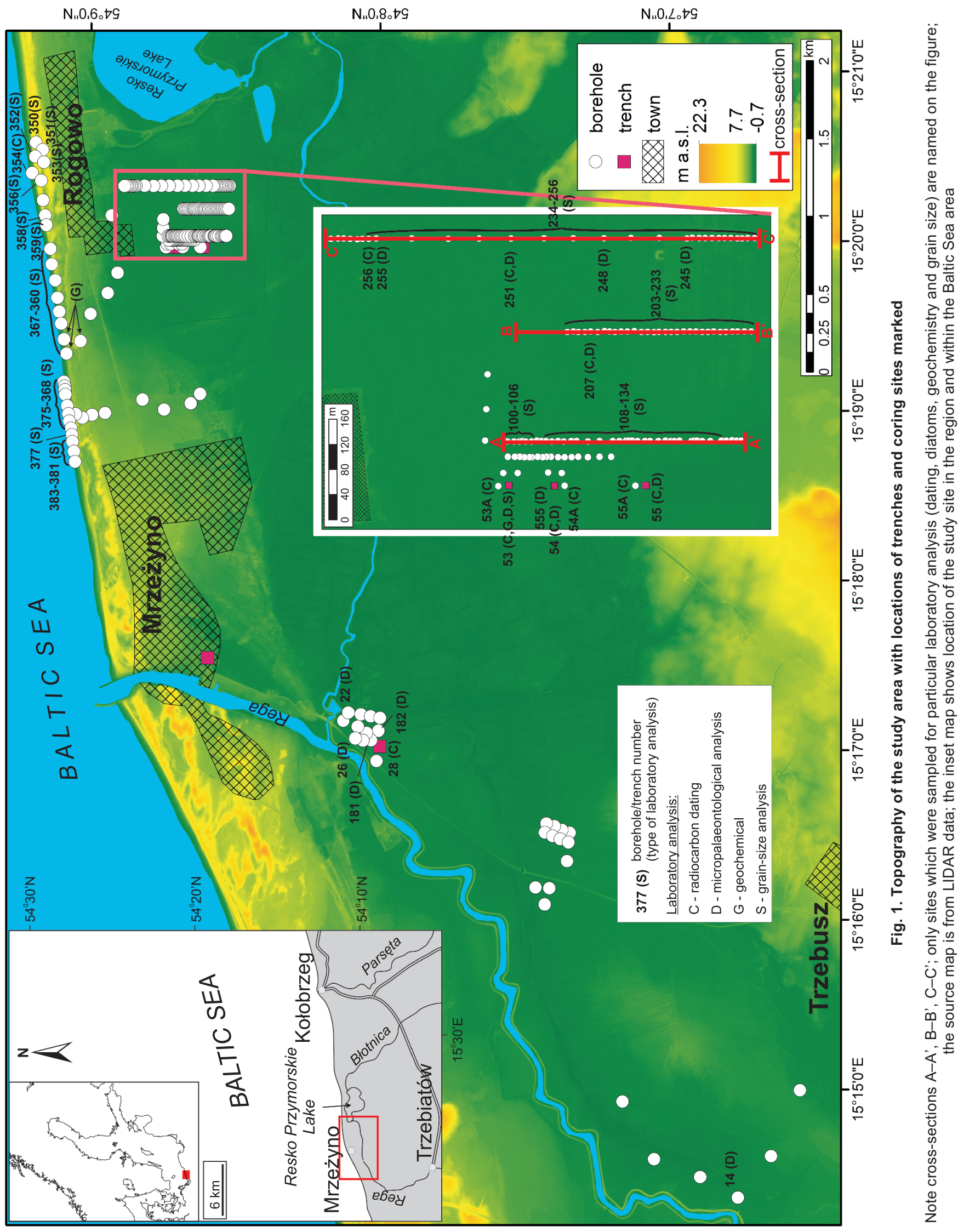
The mesh diameter interval of the sieves was 0.25 phi. Samples from trench no. 53 - dedicated to geochemical analyses were analysed using an optical diffractometry method on a laser diffraction-based Mastersizer 2000 Particle Analyzer. Statistical parameters of grain size distributions (Folk and Ward, 1957) were calculated for each sample using the GRADISTAT software (Blott and Pye, 2001).

Geochemistry. The 17 samples selected of beach and dune sands, sandy event deposits, peat and soils were analysed for loss of ignition ( $\mathrm{LOI})$, major elements $\left(\mathrm{SiO}_{2}, \mathrm{TiO}_{2}\right.$, $\mathrm{Al}_{2} \mathrm{O}_{3}, \mathrm{Fe}_{2} \mathrm{O}_{3}, \mathrm{MnO}, \mathrm{MgO}, \mathrm{CaO}, \mathrm{Na}_{2} \mathrm{O}, \mathrm{K} \mathrm{O}_{2}, \mathrm{P}_{2} \mathrm{O}_{5}, \mathrm{SO}_{3}, \mathrm{Cl}$ and $\mathrm{F})$ and trace elements (Ba, $\mathrm{Cd}, \mathrm{Co}, \mathrm{Cr}, \mathrm{Cu}, \mathrm{Mo}, \mathrm{Ni}, \mathrm{Pb}, \mathrm{Sn}, \mathrm{Sr}$, $\mathrm{V}, \mathrm{Zn}$ ). The measurements were conducted at the Central Chemical Laboratory of the Polish Geological Institute - National Research Institute in Warsaw (Poland). Major elements were measured by XRF and trace elements by ICP-OES after aqua regia digestion.

Micropalaeontological analysis. Nineteen samples for diatom, mollusc and ostracod analyses were collected from the lowermost parts of the sandy event layers in selected sediment cores and trenches. The diatom sample preparation and analysis followed the standard method outlined by Battarbee (1986). In short, sediment samples were treated with $10 \%$ hydrochloric acid $(\mathrm{HCl}), 30 \%$ hydrogen peroxide $\left(\mathrm{H}_{2} \mathrm{O}_{2}\right)$ and heated to $170^{\circ} \mathrm{C}$ in order to remove carbonates and organic matter. The microscopic slides mounted with Naphrax were analysed with a Zeiss Axio Scope A1 microscope at a magnification of 1000x. Up to 300 diatom valves were identified and counted per sample. The diatom species were classified to ecological groups using OMNIDIA software (Version 4.2) (Lecointe et al., 1993, 1999), and then the resulting groups were distinguished according to Kolbe classification (see Denys, 1991; van Dam et al., 1994).

For ostracod and mollusc analyses, the sediment was treated with $30 \% \mathrm{H}_{2} \mathrm{O}_{2}$ to digest all the organic matter, and then washed with water on a $0.1 \mathrm{~mm}$ sieve. A Nikon binocular microscope was used to identify the species present in each of the samples.

Radiocarbon dating. The chronology of the sediment samples studied and the approximate age of the event layers were based on high-precision AMS ${ }^{14} \mathrm{C}$ dating performed on bulk organic matter from soils and peat. The 26 samples were selected and after careful removal of fresh rootlets they were measured in the Poznań Radiocarbon Laboratory (Poland) using the 1.5 SDH - Pelletron Model "Compact Carbon AMS". The dates were converted into calibrated ages using the calibration program CALIB Rev 7.1 (Stuvier et al., 2016) and the IntCal13 calibration dataset (Reimer et al., 2013). Several samples contained modern, post-bomb carbon indicating a post-1960 age. To constrain the age of the samples, they were calibrated using the CALIBomb Radiocarbon Calibration program and the northern hemisphere ${ }^{14} \mathrm{C}$ datasets (Hua et al., 2013). The modern samples are presented in percent modern carbon (pMC). The calibrated results are reported with a two standard error age range.

\section{RESULTS}

\section{GENERAL SEDIMENT DESCRIPTION}

The study focused on an area $\sim 600 \mathrm{~m}$ to $>1.4 \mathrm{~km}$ from the coast, as the area closer to the coast is covered by dunes and the area further inland is strongly affected by amelioration works and agriculture. The coastal plain studied is covered by peaty soils, with a relatively high sand content, which is intercalated with one continuous sandy event layer, called here layer A (Figs. 2-4). Moreover at least one discontinuous sandy layer was documented at individual sites above layer A, e.g. in trench no. 55 (Fig. 3). The maximum lateral extent of the most extensive layer, $A$, is $>600 \mathrm{~m}$, reaching a distance of $1.2 \mathrm{~km}$ from the modern coast (Figs. 2 and 4). The thickness of this event layer varies between 0.5 and $50 \mathrm{~cm}$ (Fig. 4). The largest variations in the event layer thickness were observed at a distance of 850 to $1200 \mathrm{~m}$ from the seashore (Fig. 4). The boundary of the sandy event layer $A$ with the underlying peat is sharp and erosional. The structure is massive; no internal macroscopic stratification was noted within the layer, and it contains root traces. The layer

A
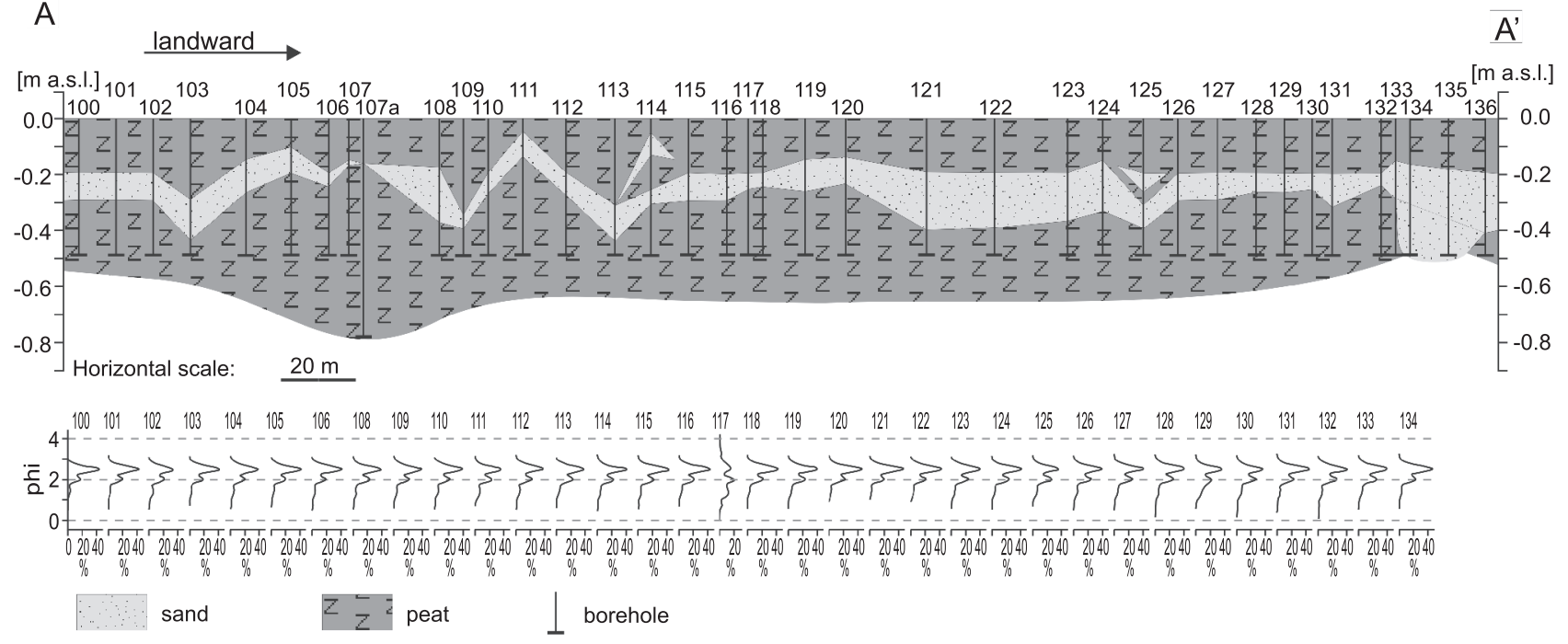

Fig. 2. An approximately $380 \mathrm{~m}$ long cross-section A-A' (see Fig. 1 for location), located next to the dated trenches and considered to be representative of the study area

The upper part presents a simplified geological cross-section; the numbers above refer to coring site number; note that the vertical scale is exaggerated; the lower panel shows grain size distributions of bulk samples taken from the major sandy event layer (A) 

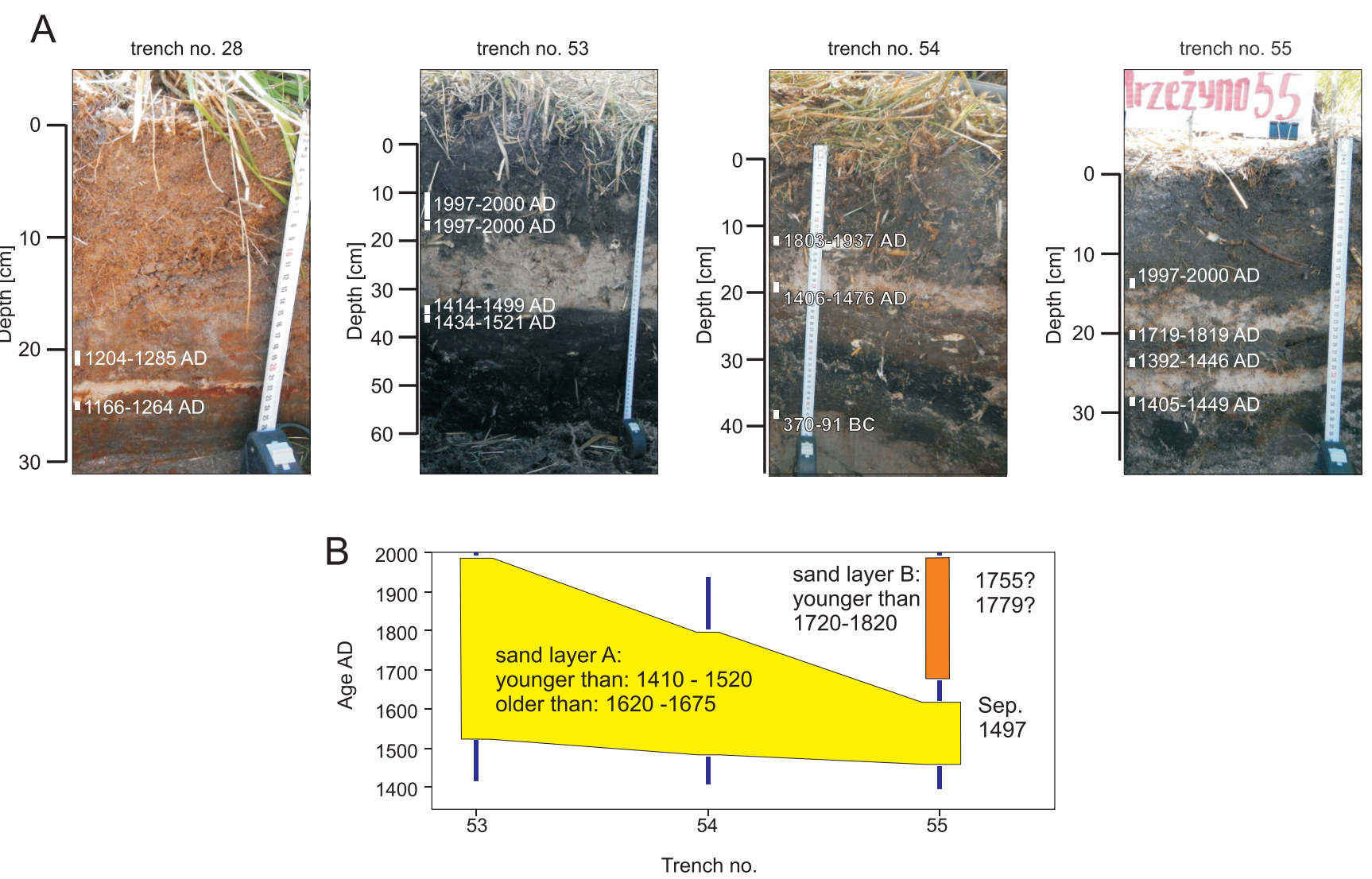

I calibrated ranges of ${ }^{14} \mathrm{C}$ dates limiting the age of event sand layers

Fig. 3. Photographs of the event layers studied in trenches no. $28,53,54,55$ and their geochronology

A- examples of stratigraphic successions in trenches with identified sandy event layers A (trench 53,54 and lower sandy layer in trench 55), $\mathrm{B}$ (upper sandy layer in trench 55) and C (trench 28); the sampling locations and 2 sigma-calibrated ${ }^{14} \mathrm{C}$ ages are included; $\mathbf{B}$ - overview of all the calibrated ${ }^{14} \mathrm{C}$ dating results for sites 53,54 and 55 (trench and coring sites next to them) from samples bracketing the major event layer (A) and younger layer $(B)$, see Appendix $1^{*}$ for detail results; see Figure 1 for trench locations

includes fragments of peat in the form of rip-up clasts (Fig. 3). The following grain size, geochemical and diatom analyses focused on this layer.

Event layer B was found in individual trench and several sediment cores (e.g., Figs. 2 and 3). It shared similar macroscopic characteristics as layer A, differing in the limited spatial distribution and smaller thickness. It was found to be $<10 \mathrm{~cm}$ thick. It cannot be excluded that layers $A$ and $B$ are amalgamated in some places.

Event layer C was found only in trench 28 (Fig. 3) and pilot trenches located up to a few metres away. It is also composed of a discontinuous layer of well-sorted sand up to $3 \mathrm{~cm}$ thick with rip-up clasts of the underlying clayey silt deposits. The latter are characterized by the common presence of iron oxides.

\section{GRAIN SIZE ANALYSIS}

Event layer $A$ is composed mostly of fine-grained sand $(90 \%$ of the samples analysed; Figs. 4-6). Medium-grained sand occurred in $9 \%$ of the samples analysed, and coarse sand in $1 \%$ of the samples. The standard deviation in most samples (78\%) shows them to be well-sorted deposits, although a slight bimodality is common in most of the samples with major modes at 2.0 and 2.5 phi (Figs. 2 and 5). Very well-sorted deposits comprise $11 \%$ of samples and moderately sorted deposits comprise $10 \%$ of samples. $79 \%$ of samples have values typical for very negative-skewed distributions and in $11 \%$ they are negative-skewed. In $7 \%$ of samples the distributions are symmetrical and in $2 \%$ they are positively skewed. Kurtosis in $82 \%$ of samples shows mesokurtic distribution curves. In $17 \%$ of samples kurtosis was platykurtic and in $1 \%$ of samples it was leptokurtic.

The grain size characteristics of event layer A does not reveal clear trends in landward direction (Fig. 4), or between particular cross-sections (Figs. 4-6). Vertical variations within the event layer are small, with a slight fining-upwards trend (Fig. 7).

Grain size analysis revealed that the event layer deposits are very similar to dune and beach deposits in terms of grain size distribution and statistics (Figs. 4-6), including the same pattern of biomodal distribution (Fig. 5). The event layer deposits revealed grain size distributions and statistics in between the 

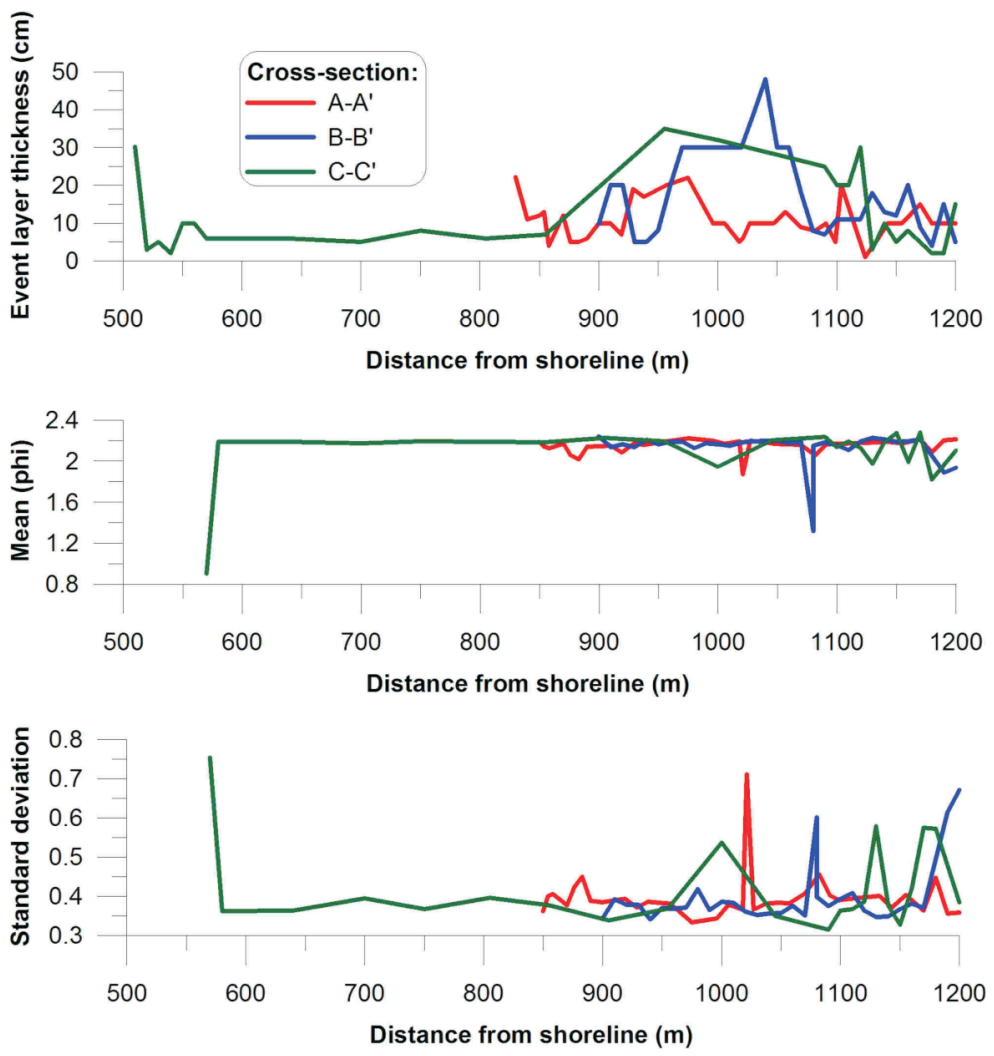

Fig. 4. Thickness, mean grain size and standard deviation of grain size distribution of the major sandy event layer (A), as documented in cross-sections $A-A^{\prime}, B-B^{\prime}$ and $C-C^{\prime}$

For locations see Figure 1

typical values for modern beach and dune deposits in the study area. The modern beach deposits are generally slightly coarser and more poorly sorted than the event deposits. The dune deposits are very uniform. They are characterized by slightly finer mean grain size and better sorting than the event and beach sediments.

\section{GEOCHEMISTRY}

The geochemical composition of beach, dune, soil and event deposits is summarized in Table 1 and in Figure 7. The concentration ranges of the major and trace elements analysed in the event deposits and in the beach sediments overlap. This is particularly the case for potential seawater indicators such as sodium and chlorine. However, the latter are only very slightly above the limits detected in dune sand and soils. It must be stressed that in the case of dune sands the geochemical composition is also very similar, however, the soils and peats sandwiching the event layer are quite different. The event layer deposits are richer in $\mathrm{SiO}_{2}$ and $\mathrm{Cl}$ than the peat and soil samples, while they are poorer in most of the remaining major and trace elements analysed (Table 1). The vertical variability of geochemical composition in event deposit A is small (Fig. 7).

\section{MICROPALAEONTOLOGICAL ANALYSIS}

All the samples taken from sandy layer $A$ reveal very similar diatom composition (Fig. 8), and contained up to 56 taxa per sample. Most of the species represent a freshwater habitat. However, several freshwater diatom species such as for example Pseudostaurosira brevistriata, Staurosira construens, Diploneis ovalis, Fragilaria sopotensis or Caloneis bacillum have been often encountered in the Baltic Sea (Hällfors, 2004). The most abundant (non Baltic Sea) freshwater taxon is Pseudostaurosira brevistriata with a percentage abundance of between 8.8 and $31.1 \%$. The main contributors to the brackish taxa community are Fragilaria martyi (9.4-56.4\%), Navicula cincta (10.1\%), N. cryptocephala $(13.9 \%)$ and $F$. subsalina $(8.4 \%)$. The characteristic marine species Diploneis stroemii was found in high abundance $(17.3 \%)$ only in one sample.

In order to show the ratio between the Baltic Sea diatom communities and other freshwater and terrestrial taxa, all brack-
A

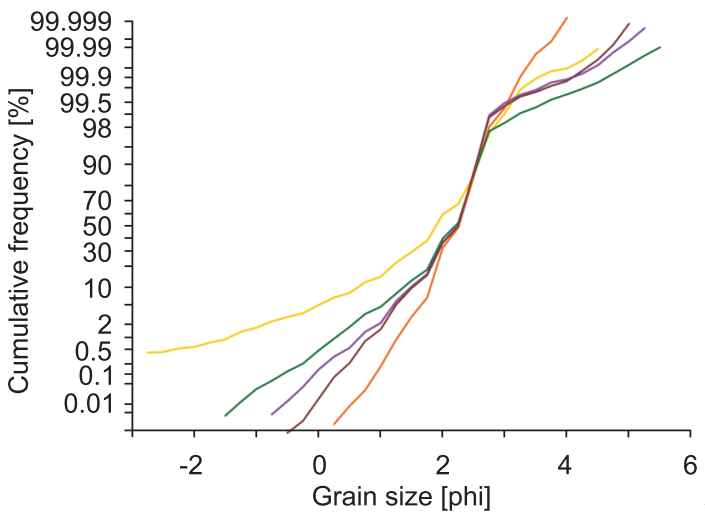

B

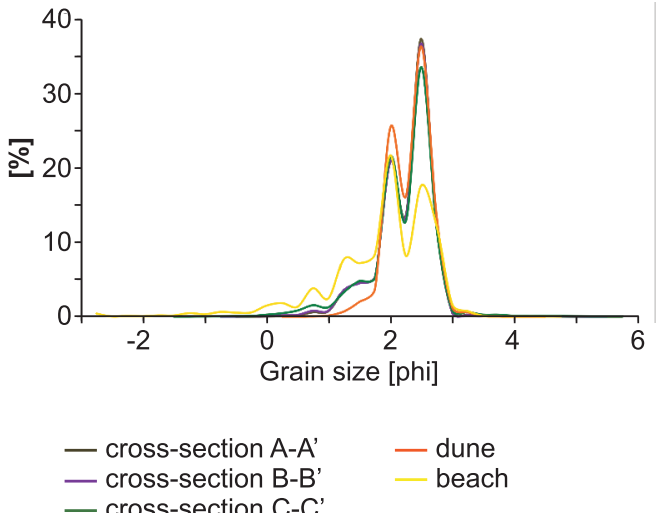

Fig. 5. Grain size distribution curves averaged for all the samples analysed taken from the event deposit layer A sampled in cross-sections A-A', B-B', C-C', as well as modern dune and beach deposits 

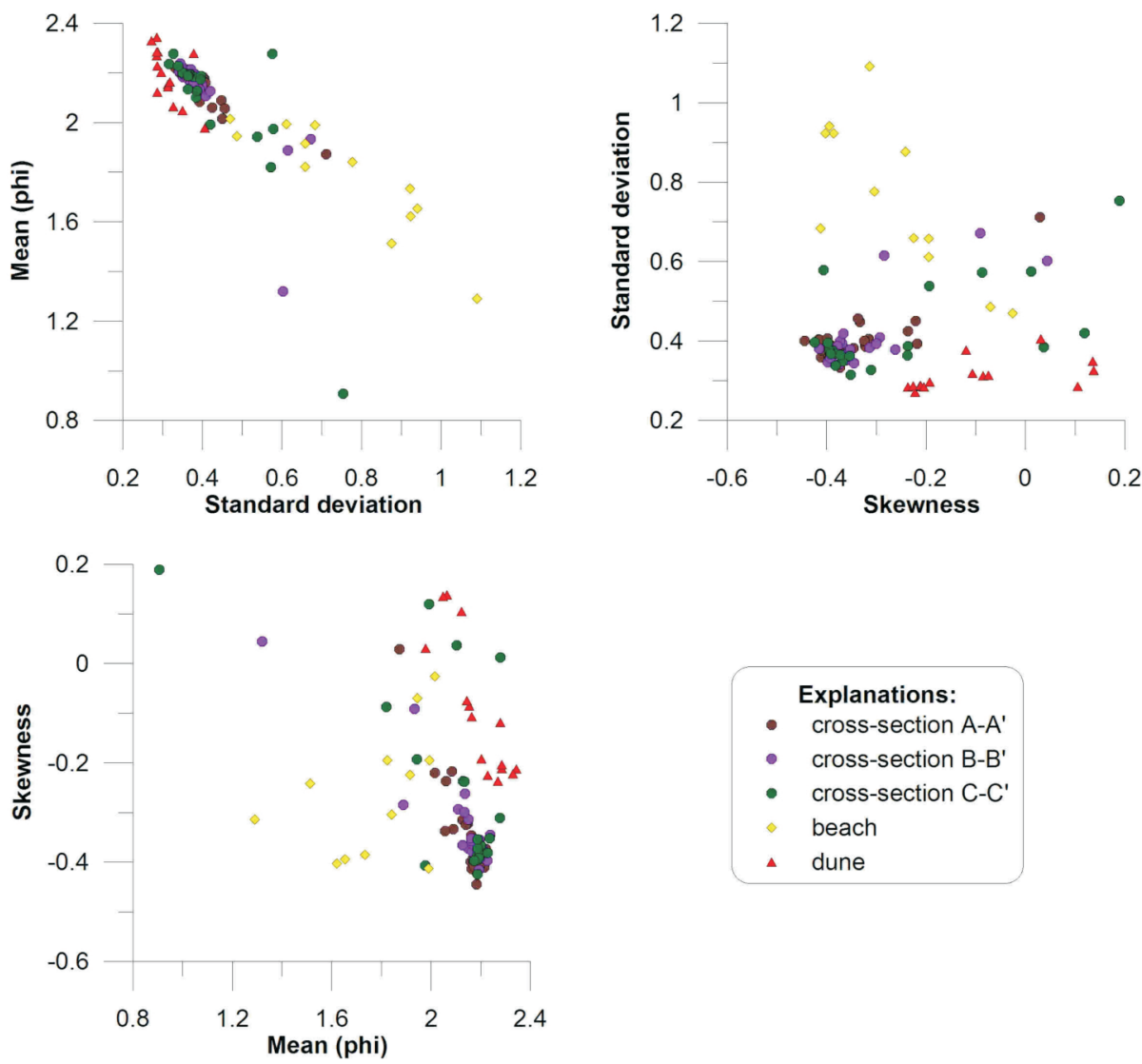

Explanations:

- cross-section A-A'

- cross-section B-B'

- cross-section C-C'

- beach

$\Delta$ dune

Fig. 6. Relationships of grain size statistics for samples taken from modern beach and dune, as well as from the sandy event layer sampled along transects $\mathrm{A}-\mathrm{A}^{\prime}, \mathrm{B}-\mathrm{B}^{\prime}$, and $\mathrm{C}^{-\mathrm{C}^{\prime}}$
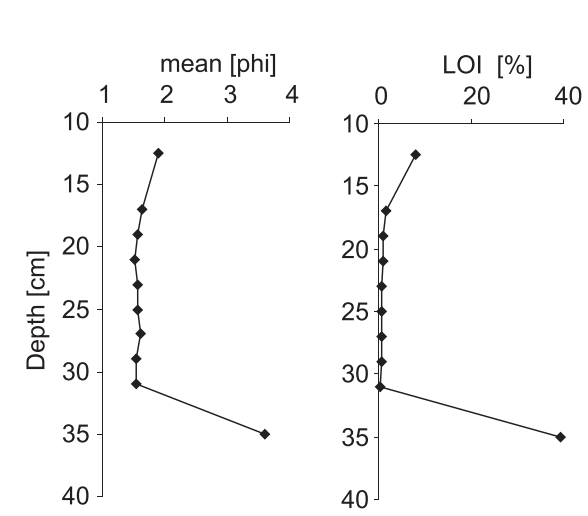

Trench no. 53

Fig. 7. Vertical changes in mean grain size, organic matter content represented by loss on ignition in $550^{\circ} \mathrm{C}$ (LOI), and oxides of selected major elements: $\mathrm{Fe}, \mathrm{Na}$ and $\mathrm{Cl}$ in trench no. 53

Samples in depth interval 16 to $33 \mathrm{~cm}$ represent sandy event deposits A, while the topmost and lowermost samples are taken from peaty soils above and below the event layer

ish, marine and Baltic Sea freshwater species have been merged into one group (Fig. 8). The average percentage abundance of the Baltic Sea diatoms was $70 \%$; the highest was $87 \%$ in core no. 255 , while the lowest $(55 \%)$ was in core no. 26 (16-22 cm and 45-46 cm) (Fig. 8).

Neither ostracods nor molluscs were found in the samples analysed.

\section{RADIOCARBON DATING}

All together 28 bulk sediment ${ }^{14} \mathrm{C}$ dates were obtained (Appendix 1). The dating strategy focused on identification of the ages of particular sandy event layers, thus most of the samples for the dating were collected just below and above the event lay- 
Table 1

Geochemistry of samples from modern beach, dune, modern and old soils and peat deposits as well as of the investigated sandy event layer A (provided are ranges of values in samples from particular groups)

\begin{tabular}{|l|c|c|c|c|}
\hline & Beach & Dune & Soil/peat & Event layer \\
\hline $\mathrm{No} \mathrm{samples}$ & 2 & 1 & 4 & 10 \\
\hline $\mathrm{SiO}_{2} \%$ & $95.3-95.8$ & 87.2 & $51.8-86.2$ & $93.7-95.3$ \\
\hline $\mathrm{TiO}_{2} \%$ & 0.20 & 0.27 & $0.17-0.23$ & $0.08-0.21$ \\
\hline $\mathrm{Al}_{2} \mathrm{O}_{3} \%$ & $1.7-2.1$ & 2.26 & $2.6-3.5$ & $2.1-2.5$ \\
\hline $\mathrm{Fe}_{2} \mathrm{O}_{3} \%$ & $0.36-0.39$ & 0.49 & $0.7-1.9$ & $0.2-0.4$ \\
\hline $\mathrm{MnO} \%$ & 0.02 & 0.02 & $0.02-0.07$ & $0.01-0.02$ \\
\hline $\mathrm{MgO} \%$ & $0.07-0.08$ & 0.05 & $0.11-0.37$ & $0.03-0.05$ \\
\hline $\mathrm{CaO} \%$ & $0.29-0.3$ & 0.27 & $0.4-1.3$ & $0.2-0.27$ \\
\hline $\mathrm{Na}_{2} \mathrm{O} \%$ & $0.43-0.5$ & 0.43 & $0.44-0.53$ & $0.46-0.56$ \\
\hline $\mathrm{K}_{2} \mathrm{O} \%$ & $0.52-0.68$ & 0.72 & $0.83-0.96$ & $0.76-0.94$ \\
\hline $\mathrm{P}_{2} \mathrm{O}_{5} \%$ & 0.03 & 0.04 & $0.08-0.31$ & $0.02-0.03$ \\
\hline$(\mathrm{SO})_{3} \%$ & $<0.01$ & $<0.01$ & $<0.01-0.05$ & $<0.01$ \\
\hline$(\mathrm{Cl} \%$ & $0.02-0.03$ & 0.02 & $0.01-0.02$ & $0.02-0.03$ \\
\hline$(\mathrm{F}) \%$ & $0.06-0.07$ & 0.02 & $<0.01-0.05$ & $<0.01-0.1$ \\
\hline $\mathrm{LO} \%$ & $0.35-0.51$ & 8.34 & $7.92-39.32$ & $0.47-1.65$ \\
\hline $\mathrm{As} \mathrm{mg} / \mathrm{kg}$ & $<3$ & $<3$ & $<3-6$ & $<3$ \\
\hline $\mathrm{Ba} \mathrm{mg} / \mathrm{kg}$ & $16-18$ & 12 & $20-50$ & $10-23$ \\
\hline $\mathrm{Cd} \mathrm{mg} / \mathrm{kg}$ & $<0.5$ & $<0.5$ & $<0.5$ & $<0.5$ \\
\hline $\mathrm{Co} \mathrm{mg/kg}$ & $<1$ & $<1$ & $<1-1$ & $<1$ \\
\hline $\mathrm{Cr} \mathrm{mg} / \mathrm{kg}$ & 1 & 1 & $7-18$ & $<1-2$ \\
\hline $\mathrm{Cu} \mathrm{mg} / \mathrm{kg}$ & $<1-1$ & 6 & $3-8$ & $<1-2$ \\
\hline $\mathrm{Mo} \mathrm{mg} / \mathrm{kg}$ & $<0.5$ & $<0.5$ & $<0.5-0.9$ & $<0.5$ \\
\hline $\mathrm{Ni} \mathrm{mg} / \mathrm{kg}$ & $<1$ & 2 & $2-7$ & $<1$ \\
\hline $\mathrm{Pb} \mathrm{mg} / \mathrm{kg}$ & $<2$ & 8 & $11-25$ & $<2-3$ \\
\hline $\mathrm{Sn} \mathrm{mg} / \mathrm{kg}$ & $<2$ & $<2$ & $<2$ & $<2$ \\
\hline $\mathrm{Sr} \mathrm{mg} / \mathrm{kg}$ & 7 & 5 & $10-37$ & $4-6$ \\
\hline $\mathrm{V} \mathrm{mg} / \mathrm{kg}$ & 2 & 2 & $11-32$ & $<1-3$ \\
\hline $\mathrm{Zn} \mathrm{mg} / \mathrm{kg}$ & $3-4$ & 13 & $9-46$ & $2-5$ \\
\hline & & & & \\
\hline
\end{tabular}

ers. The lowermost part of the coastal peat sequence was dated in order to provide likely time span of its development. The oldest ages from the lowermost part of the peat sequence are from 370 to 91 calibrated years BC. Thus, the succession studied represents approximately the last two thousand years.

The age of layer $A$ is established on the basis of 8 samples taken just below the layer and 6 samples collected above it (Appendix 1 and Fig. 3). All the samples predating the event provide very similar calibrated age ranges covering the 14th and 15th century $A D$. The oldest calibrated age range is $1301-1368$ AD, while the youngest is 1414-1499 AD. The peat samples collected above the event layer represent two groups of ages. The first group represents samples from sites where event layer $A$ is a single layer. In these samples the ages are modern (19th and 20th century), likely due to contribution from modern plants. In sites where the younger event layer B is present (younger than 17th century), the calibrated age ranges of the peat above layer $A$ are in a similar range to the samples just underneath the layer, namely in the range of 1392-1449 AD. The oldest sample taken some distance above layer $A$ is peat underlying layer $B$, dated to 1620-1675 AD. The most likely historical event which may correspond to the formation of the layer A is the catastrophic storm of the 17th of September 1497. The slightly older ages of some samples collected just above the sandy layer may be related to contribution of older organic matter, likely from erosion of pre-event peat, redeposited after the emplacement of the sandy layer.

The age of layer B is based on two sets of samples taken from underneath and above the event layer (Appendix 1 and Fig. 3). The calibrated age ranges of the peat below the layer are 1719-1819 AD and 1621-1675 AD. The difference may be due to erosion of some pre-event peat, which is likely due to the presence of rip-up clasts in the event deposits. However, contamination with younger organic matter due to modern plants root penetration cannot be completely ruled out. Both samples taken above the layer provide modern ages. Taking into account the youngest ages of the pre-event peat, the age of the event likely took place during the 18th century or shortly afterwards. The historical record includes at least two events which could be related to that layer, the "Seebär" from 1757 AD already noted or a major regional storm in $1779 \mathrm{AD}$.

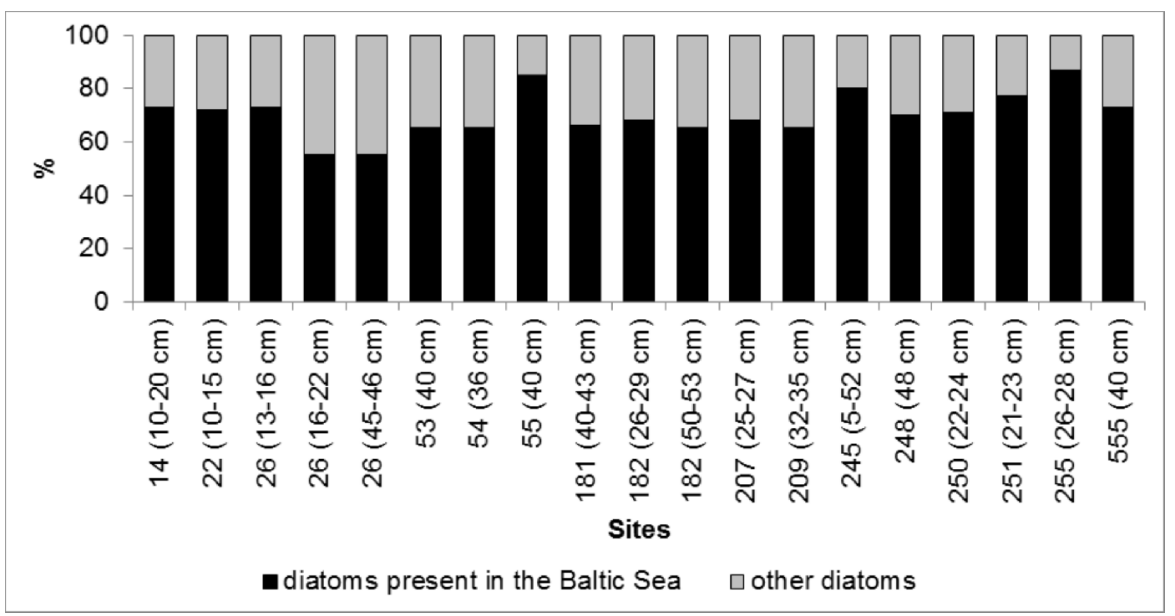

Fig. 8. Proportions of diatoms common in the modern Baltic Sea and other freshwater diatoms present in samples collected from sandy event layer $A$ 
The age of layer $\mathrm{C}$ encountered in trench no. 28 (Figs. 1 and 3 ) is based on two samples taken from below and above the layer. They provide overlapping age ranges: 1166-1266 AD and 1204-1285 AD, respectively. Thus the event likely took place at the beginning of the 13th century. No historical record of this event has been found.

\section{RESULTS AND DISCUSSION}

\section{ORIGIN OF THE EVENT LAYERS}

Geological identification of past marine catastrophic inundations (tsunamis and storms) is important for coastal zone risk assessment studies, especially in areas where the historical record is limited or absent (e.g., Jankaew et al., 2008; Goto et al., 2014). The main problem when using the geological evidence is to correctly identify the sedimentary record, in particular in distinguishing between tsunami and storm deposits. Both of these are high-energy events that may leave coarser event deposits containing marine indicators in coastal stratigraphic sequences (e.g., Kortekaas and Dawson, 2007; Morton et al., 2007; Goff et al., 2012; Chagué-Goff et al., 2017; Soria et al., 2017). Moreover, one always needs to take into account potential post-depositional changes of the deposits (e.g., Szczuciński, 2012).

The present study revealed the presence of three sand layers (Fig. 3) deposited and preserved on the coastal plain near Rogowo and Mrzeżyno. All of these share several characteristics of event deposits. They are composed of coarser, sandy sediments containing rip-up clasts of underlying soil or peat. The ${ }^{14} \mathrm{C}$ dates of organic matter from below and above them represent a short time span and thus suggest that the sand layers represent short-lasting events. Since the study area is in the coastal zone, close to a river valley, several possible origins of the event layers are possible including storms, tsunami, river floods and wind transport.

Sand layer A is continuous, it extends for over $600 \mathrm{~m}$ inland, and is very homogeneous in terms of grain size distribution alongshore as well as in a landward direction (Figs. 2-4). The thickness of the layer varies between a few and $20 \mathrm{~cm}$, but in some cores it is up to $50 \mathrm{~cm}$ thick. Its grain size distributions and statistics suggest that the sediment may be of mixed dune and beach origin (Figs. 5 and 6 ). The structure is massive and vertical grain size variations (Fig. 7) reveal a slight fining-upwards trend. The basal contact is sharp and erosional, as rip-up clasts of underlying peat are present in the layer. The layer contains slightly increased concentrations of $\mathrm{Na}$ and $\mathrm{Cl}$ (Fig. 7) and significant content of diatoms typical of the Baltic Sea (Fig. 8). Ostracods and molluscs were not present in the samples analysed. The ages of the underlying peat provide calibrated age ranges encompassing the 14 and 15th centuries AD. While some above-layer ages are similar, where a sand layer $B$ is also present, modern ages were found in cases of where no overlying event layer was present.

The geomorphological position, extent, grain size characteristics and presence of marine indicators in layer A seem to favour a storm or tsunami rather than a flood (e.g., Skolasińska et al., 2015; Matsumoto et al., 2016) or wind-blown origin of the event layer. However, one cannot exclude some post-depositional modification of the event layer due to wind transport after deposition, as was observed for instance after the 2011 Tohoku-oki tsunami on Sendai Plain, where sandy tsunami deposits were partly reworked by winds (Richmond et al., 2012). This may be for instance a reason for the observed increased sand layer thickness near the landward limit of the deposits (Fig. 4). A similar observation was made by Williams (2015) on recent North Atlantic hurricane deposits, which were partly redeposited landward due to onshore directed winds during the final phase of hurricane.

A marine origin for the event layer is not easily demonstrated in the case of the Baltic Sea, as it is a brackish sea with very low salinity, 5 to $18 \mathrm{PSU}$ in coastal waters of the southern Baltic Sea (Krzymiński et al., 2004). So, it is not surprising that the geochemical signature of salinity is only slight (Fig. 7). However, as salinity indicators are usually poorly preserved in sandy deposits (e.g., Chagué-Goff et al., 2017), the documented increase in $\mathrm{Na}$ and $\mathrm{Cl}$ may be meaningful. Ostracods and molluscs were not present in the samples analysed. However, their preservation depends on post-burial conditions. Peaty lowland deposits are characterized by a large amount of humic acid resulting in low $\mathrm{pH}$, possibly leading to dissolution of carbonate shells. The complete dissolution of carbonate fossils and microfossils is a common phenomenon in acidic coastal settings (e.g., Szczuciński et al., 2016). In such a case siliceous remnants of diatoms are useful indicator. The Baltic Sea due to its low salinity is a habitat for marine, brackish species but also some species considered to be freshwater. All these groups are also found in the event layer A (Fig. 8). Moreover, a marine origin of the deposits may be interpreted from the grain size of the deposits, which seem to be of mixed source including coastal dune and beach provenance.

It proved very difficult to distinguish between a tsunami deposit and storm deposits, especially in sediment cores, but also in some trench sections. Comparative studies (e.g., Nanayama et al., 2000; Goff et al., 2004; Tuttle et al., 2004; Kortekaas and Dawson, 2007; Morton et al., 2007) showed that although both types of deposits share many characteristics, several features may be considered more typical of storm or tsunami deposits. Storm deposits are often laminated, have shorter landward extent and reach thicknesses of several tens of centimetre or more. Tsunami deposits are often more extensive and thinner (from a few $\mathrm{mm}$ to $<0.5 \mathrm{~m}$ ) than storm deposits. Tsunami deposits are also often massive or fine upwards, contain intraclasts from underlying material (rip up clasts), are poorer sorted, and are capped with mud laminae. However, in documentation of recent storms and tsunamis, features considered to be typical of storms are found in tsunami deposits (e.g., Szczuciński et al., 2012a, b) and those considered to be characteristic of a tsunami may be present in storm deposits (e.g., Soria et al., 2017).

Taking into account the criteria noted above the sand layer A seems to contain more features typical of tsunami deposits: a sharp lower contact, wide extent, massive structure with slight grain size upward fining and rip-up clasts. However, the dating of the event suggest that it is likely related to 17th September 1497 event. That event is reported as one of the strongest storms in historical records, causing extensive flooding of the coastal zone along a large part of the southern Baltic Sea coast (Piotrowski, 2007b). Due to its extent and size with runup height in Darłowo reported to possibly reach up to $20 \mathrm{~m}$ a.s.l., as well as one of the biggest historical earthquakes in Sweden being reported in the same year, Piotrowski (2007b) considered a possible contribution to that event also from tsunami. However, the more recent historical earthquake catalogue (Kulhanek and Persson, 2011) specified the date of the 4.8 magnitude earthquake to be 20th January 1497, so excluding its contribution to that storm event. The local historical descriptions from the Rogowo region mention the complete erosion of a barrier spit next to the nearby Resko Przymorskie Lake (Fig. 1) by a storm 
Comparison of historical information and geological record of the tsunami/storm events

\begin{tabular}{|c|c|c|}
\hline Event & Historical descriptions & Geological record \\
\hline $\begin{array}{l}\text { 17th of } \\
\text { September } 1497\end{array}$ & $\begin{array}{l}\text { - storm } \\
\text { - many ships damaged, } \\
\text { - noted along }>500 \mathrm{~km} \text { of southern Baltic Sea } \\
\quad \text { coast, } \\
\text { - lasted more than } 2 \text { days, } \\
\text { - local runup height maybe up to } 20 \mathrm{~m} \text { a.s.l. in } \\
\quad \text { Darłowo, } \\
\text { - } \text { saltwater inundation }\end{array}$ & $\begin{array}{l}\text { - massive sand layer from dune and beach erosion, } \\
\text { - the layer is up to } \sim 50 \mathrm{~cm} \text { thick and extends up to } 1.2 \mathrm{~km} \text { inland } \\
\text { - soil rip-up clasts, } \\
\text { - contains marine diatoms, } \\
\text { - enriched in } \mathrm{Na} \text { and } \mathrm{Cl}, \\
\text { - interpreted as a storm surge flooding of a lowland plain } \\
\quad(\sim-0.5 \text { to }+0.5 \mathrm{~m} \text { a.s.I. }) \text { with marine waters after coastal } \\
\text { dunes erosion }\end{array}$ \\
\hline 3th of April 1757 & $\begin{array}{l}\text { - calm and bright sky, } \\
\text { - peculiar roar or thunder, } \\
\text { - in other descriptions the sound effect, } \\
\text { is like ammunition storage explosion, } \\
\text { - retreat of the water before surge, } \\
\text { - three inundations (waves) }\end{array}$ & $\begin{array}{l}\text { - non-continuous, massive sand layer, } \\
\text { - soil rip-up clasts, } \\
\text { - interpreted as a flooding of lowland, plain ( }-0.5 \text { to }+0.5 \mathrm{~m} \text { a.s.I.) } \\
\text { with marine waters during tsunami-like event (meteotsunami, } \\
\text { landslide-generated tsunami) or storm (not related to the noted } \\
\text { historical account) }\end{array}$ \\
\hline
\end{tabular}

lasting more than 2 days (Table 2). Thus it was likely the storm surge event that most plausibly formed the extensive sand sheet on the coastal plain.

The possible mechanism of formation of tsunami-like deposits by storm surge is shown in Figure 9. We consider the local topography to be of importance. The dune at Rogowo is relatively low in contrast to high barriers elsewhere along the coast. Moreover, low-lying terrain landward of the dunes caused specific conditions for formation of the event layer. During the extreme, long-lasting storm the water level may be set-up by a couple of metres along the coast. This leads to a situation where sea level is several metres higher than the coastal lowland behind the dunes. The overtopping of dunes, or dune breaching could cause a massive saltwater inundation of the coastal plain, likely supported by strong onshore wind. Thus, the low-lying coastal plain could have been inundated by unidirectional flow - similar to that observed in case of tsunamis. Low elevations could promote unconfined flow and construction of washover terraces or sheetwash deposits (Morton and Sallenger, 2003). Backwash probably did not occur until the
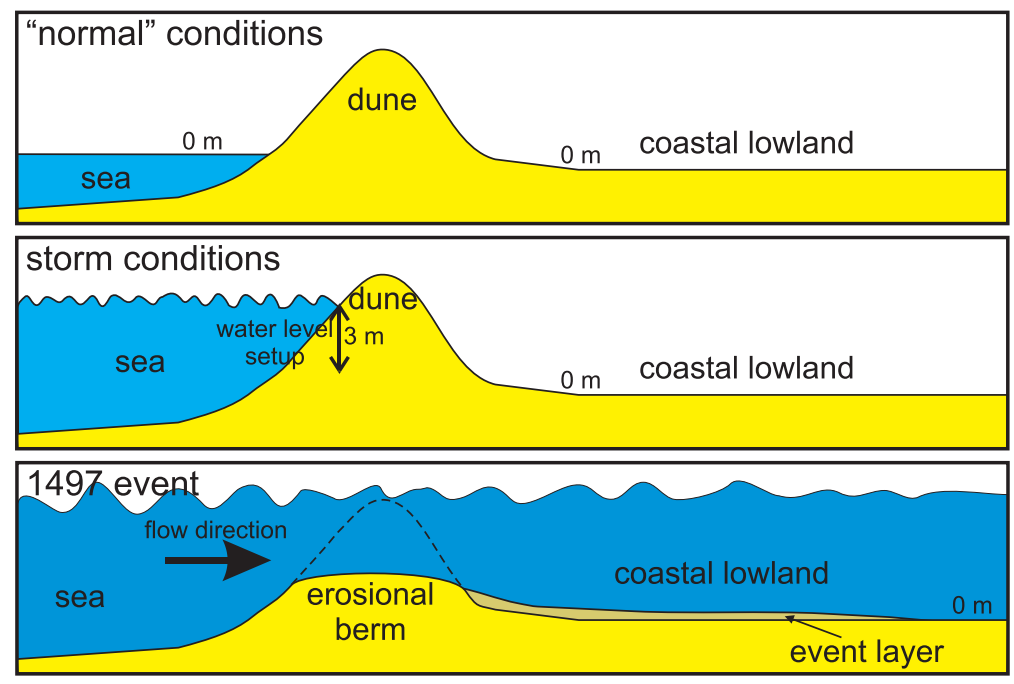

Fig. 9. A simple conceptual model showing the possible situation during "normal" conditions, storm conditions and a possible scenario during the 1497 AD extreme storm surge event leading to formation of extensive sandy deposit layer A, documented in the present contribution storm ceased, but this is also the case in tsunamis flooding coastal plains, where water is ponded for a long period of time (e.g., Chagué-Goff et al., 2012; Tappin et al., 2012).

Sand layer $B$ shares many sedimentological similarities with sand layer A, including an erosional contact, a thickness of $>10$ $\mathrm{cm}$ and the presence of rip-up clasts. However, its extent is much more confined, although it is not possible to exclude some amalgamation of event layers. The dating suggests that the origin of the layer could be related to strong storms which were common along the southern Baltic Sea coast in the 18th century, resulting in a similar scenario to the one described above for the 1497 event. However, an alternative genesis of these deposits is the "Seebär" from 1757 AD. A comparison of historical accounts and sedimentological expressions of this event is shown in Table 2. The evidence provided cannot allow certain determination of the origin of the deposits studied. Taking into account that a tsunami ("Seebär") could take place during lower sea level (calm conditions) it might be more likely that a storm surge with set-up of sea water level by a couple of metres is responsible for the formation of the layer.

Layer C was found only in a small area. This may be due to its limited preservation or its limited original extent. The location of the layer close to the Rega River may suggest that it is a record of a former flood event. Taking into account the timing of the event at the beginning of the 13th century, one must keep in mind that the Rega River was entering the Baltic not at its present position, as it then flowed through the Resko Przymorskie Lake (Fig. 1), so marine inundation along the river valley is less likely. The beginning of the 13th century was also a time of increased precipitation in Poland (Gałka et al., 2013; Starkel et al., 2013).

\section{IMPLICATIONS FOR COASTAL HAZARD ASSESSMENT}

This case study shows that some extreme saltwater inundations reported in historical accounts may also be partly reconstructed using the geological record. The record has some limitations due to preservation issues, changes of coastline position with time and human engineering actions. Moreover, the observations suggest that it is likely impos- 
sible in some cases to distinguish storm surge from tsunami deposits (Table 2). Nevertheless, it is important to look for such geological records to constrain a worst case scenario. This is particularly needed along the Baltic Sea coasts where coastal hazards due to catastrophic events are little recognized while at the same time large infrastructure investments are being considered, e.g. nuclear power plants. The probable geological record of the 1497 storm event reported here, which was possibly the greatest such event of the last 2000 years, provides a kind of minimum estimate of what may happen during such an event, when the coastal plain may be flooded more than $1 \mathrm{~km}$ inland.

\section{CONCLUSIONS}

Three sandy event layers have been identified in the coastal peat and clayey deposits developed during the last $\sim 2000$ years. The most extensive layer reveals a number of typical features of tsunami deposits (significant lateral extent, thickness, rip-up clasts, chemical and micropalaeontological evidence of marine origin). Precise ${ }^{14} \mathrm{C}$ dating along with historical accounts showed that the major layer, extending at least $1.2 \mathrm{~km}$ from the modern coast, was likely deposited by the biggest storm surge during the last 2000 years, which took place in 1497. These storm deposits were likely formed during inunda- tion of the low-lying coastal plain after major breaching of coastal dunes resulting in a tsunami-like flow pattern and similar sedimentological effects. Two discontinuous sand layers were likely deposited by river flood (at the beginning of the 13th century) and by storm surge or a "Seebär" tsunami-like event of younger age (18th century). The study revealed that the southern Baltic Sea coast may be affected by much larger coastal floods than are known from more recent records and observations, something that should be taken into account in coastal hazard assessment.

The event deposits documented, which resemble tsunami deposits, are likely of storm surge origin. In specific settings (coastal plain, low coastal dunes) a storm surge may cause unidirectional inundation of a coastal plain and leave deposits alike tsunami deposits. Thus in such cases storm or tsunami origin may not be distinguishable.

Acknowledgements. The research was funded by the $\mathrm{Na}-$ tional Science Centre in Poland grant No. 2011/01/B/ST10/07220. We would like to thank J. Seidler for help in diatom analysis, M. Mitręga for assistance in grain size analysis, and T. Goslar and his team for AMS ${ }^{14} \mathrm{C}$ dating. The constructive reviews by R. Jagodziński, A. Kotilainen and N.-A. Mörner, as well as editorial corrections by E. Dąbrowska-Jędrusik are kindly acknowledged.

\section{REFERENCES}

Andrade, C., 1992. Tsunami generated forms in the Algarve barrier islands. Science of Tsunami Hazards, 10: 21-33.

Averkiev, A.S., Klevannyy, K.A., 2007. Determining cyclone trajectories and velocities leading to extreme sea level rises in the Gulf of Finland. Russian Meteorology Hydrology, 32: 514-519.

Averkiev, A.S., Klevannyy, K.A., 2010. A case study of the impact of cyclonic trajectories on sea-level extremes in the Gulf of Finland. Continental Shelf Research, 30: 707-714.

Battarbee, R.D., 1986. Diatom analysis. In: Handbook of Holocene Paleoecology and Paleohydrology (ed. B.E. Berglund): 527-570. John Wiley and Sons.

Blott, S.J., Pye, K., 2001. GRADISTAT: a grain size distribution and statistics package for the analysis of unconsolidated sediments. Earth Surface Processes Landforms, 26: 1237-1248.

Bourgeois, J., 2009. Geologic effects and records of tsunamis. In: The Sea. Tsunamis, 15 (eds. A.R. Robinson and E.N. Bernard): 55-91. Harvard University Press, Cambridge, USA

Brüggemann, L.W., 1779. Ausfuerliche Beschreibung des Gegenwärtiges Zustandes des Koeniglieschen Preußischen Herzogtums Vor- und Hinterpommern. Stettin.

Cedro, B. ed., 2012. Późnoglacjalne i holoceńskie przemiany środowiska przyrodniczego zarejestrowane w osadach profilu T28 z okolic Mrzeżyna na podstawie badań wielodyscyplinarnych (in Polish). Przedsiębiorstwo Produkcyjno-Handlowe ZAPOL Dmochowski, Sobczyk Sp.j.

Chagué-Goff, C., 2010. Chemical signatures of paleotsunamis: a forgotten proxy? Marine Geology, 271: 67-71.

Chagué-Goff, C., Schneider, J.-L., Goff, J.R., Dominey-Howes, D., Strotz, L., 2011. Expanding the proxy toolkit to help identify past events - lessons from the 2004 Indian Ocean Tsunami and the 2009 South Pacific Tsunami. Earth-Science Reviews, 107: 107-122.

Chagué-Goff, C., Niedzielski, P., Wong, H.K.Y., Szczuciński, W., Sugawara, D., Goff, J., 2012. Environmental impact assess- ment of the 2011 Tohoku-oki tsunami on the Sendai Plain. Sedimentary Geology, 282: 175-187.

Chagué-Goff, C., Szczuciński, W., Shinozaki, T., 2017. Applications of geochemistry in tsunami research: a review. Earth-Science Reviews, 165: 203-244.

Credner, R., 1889. Über den "Seebär” der westlichen Ostsee vom 16/17 Mai 1888. Jahrbuch der Geographischen Gesellschaft Greifswald, R.3.

Denys, L., 1991. A checklist of the diatoms in the Holocene deposits of the western Belgian coastal plain with a survey of their apparent ecological requirements. Belgische Geologische Dienst, Professional Paper, 1991/2: 246.

Dobracka, E., 1990. Szczegółowa mapa geologiczna Polski 1:50000, arkusz Trzebiatów (78) (in Polish). Państwowy Instytut Geologiczny, Warszawa.

Dobracka, E., 1992. Objaśnienie do Szczegółowej mapy geologicznej Polski w skali 1:50 000, arkusz Trzebiatów (78) (in Polish). Państwowy Instytut Geologiczny, Warszawa.

Dobracki, R., Zachowicz, J., 1997. Mapa geodynamiczna polskiej strefy brzegowej Bałtyku południowego w skali 1:10 000 arkusze Mrzeżyno i Dźwirzyno (in Polish). Państwowy Instytut Geologiczny, Szczecin.

Dominay-Howes, D.T.M., Humphreys, G.S., Hesse, P.P., 2006. Tsunami and palaeotsunami depositional signatures and their potential value in understanding the late-Holocene tsunami record. The Holocene, 16: 1095-1107.

Dziadziuszko, Z., Jednorał, T., 1996. Flooding threat caused by storm surges at the coast of Baltic Sea and Vistula Lagoon (in Polish with English summary). Wiadomości Instytutu Meteorologii i Gospodarki Wodnej, 19: 123-133.

Folk, R.L., Ward, W.C, 1957. Brazos River bar, a study of significance of grain size parameters. Journal of Sedimentary Petrology, 27: 3-26.

Gałka, M., Miotk-Szpiganowicz, G., Goslar, T., Jęśko, M., van der Knaap, W.O., Lamentowicz, M., 2013. Palaeohydrology, fires 
and vegetation succession in the southern Baltic during the last 7500 years reconstructed from a raised bog based on multi-proxy data. Palaeogeography, Palaeoclimatology, Palaeoecology, 370: 209-221.

Goff, J., McFadgen, B.G., Chagué-Goff, C., 2004. Sedimentary differences between the 2002 Easter storm and the 15th-century Okoropunga tsunami, southeastern North Island, New Zealand. Marine Geology, 204: 235-250.

Goff, J., Chagué-Goff, C., Nichol, S., Jaffe, B., Dominey-Howes, D., 2012. Progress in palaeotsunami research. Sedimentary Geology, 243-244: 70-88

Goto, K., Kawana, T., Imamura, F., 2010. Historical and geological evidence of boulders deposited by tsunamis, southern Ryukyu Islands, Japan. Earth-Science Reviews, 102: 77-99.

Goto, K., Fujino, S., Sugawara, D., Nishimura, Y., 2014. The current situation of tsunami geology under new policies for disaster countermeasures in Japan. Episodes, 37: 258-264.

Gurwell, B., 2008. Coastal protection along the Baltic Sea coast Mecklenburg-Vorpommern. Die Küste, 74: 179-188.

Hällfors, G., 2004. Checklist of Baltic Sea phytoplankton species (including some heterotrophic protistan groups). Baltic Sea Environment Proceedings, 95.

Hua, Q., Barbetti, M., Rakowski, A.Z., 2013. Atmospheric radiocarbon for the period 1950-2010. Radiocarbon, 55: 2059-2072.

Hupfer, P., Harff, J., Sterr, H., Stigge, H.J., 2003. Wasserstände an der Ostsee Küste. Die Küste, 66: 4-331.

Jankaew, K., Atwater, B., Sawai, Y., Choowong, M. Charoentitirat, T., Martin, M., Prendergast, A., 2008. Medieval forewarning of the 2004 Indian Ocean tsunami in Thailand. Nature, 455: 1228-1231.

Jensen, J., Müller-Navarra, S.H., 2008. Storm surges on the German Coast. Die Küste, 74: 92-124.

Kortekaas, S., 2002. Tsunamis, storms, and earthquakes: distinguishing coastal flooding events. Ph.D. thesis, Coventry University, UK.

Kortekaas, S., Dawson, A.G., 2007. Distinguishing tsunami and storm deposits: an example from Martinhal, SW Portugal. Sedimentary Geology, 200: 208-221.

Krzymiński, W., Kruk-Dowgiałło, L., Zawadzka-Kahlau, E., Dubrawski, R., Kamińska, M., Lysiak-Pastuszak, E., 2004 Typology of Polish marine waters. Coastline Reports, 4: 39-48.

Kulhanek, O., Persson, L., 2011. Macroseismic observations of Swedish earthquakes from 1375 to 2000. SGU (Geological Survey of Sweden) Research Paper, C 837

Lario, J., Luque, L., Zazo, C., Goy, J.L., Spencer, Ch., Cabero, A., Bardaji, T., Borja, F., Dabrio, C.J., Civis, J., Gonzalez-Delgado, J.A., Borja, C., Alonso-Azcarate, J., 2010. Tsunami vs. storm surge deposits: a review of the sedimentological and geomorphological records of extreme wave events (EWE) during the Holocene in the Gulf of Cadiz, Spain. Zeitschrift fur Geomorphologie, 54, Suppl., 3: 301-316.

Lecointe, C., Coste, M., Prygiel, J., 1993. "OMNIDIA": software for taxonomy, calculation of diatom indices and inventories management. Hydrobiologia, 269/270: 509-513.

Lecointe, C., Coste, M., Prygiel, J., Ector, L., 1999. Le logiciel OMNIDIA version 3, une puissante base de données pour les inventaires de diatomées et pour le calcul des diatomiques européens. Cryptogamie Algologie, 20: 132-134.

Luque, L., Zazo, C., Lario, J., Goy, J.L., Civis, J., Lopez-Gonzales, F.M., Silva, P.G., Dabrio, C.J., 2004. El efecto del tsunami de 1755 en el litoral de Conil de la Frontera (Cadiz). Zona Arqueologica, 4. Miscelanea en Homenaje a Emiliano Aguirre. V-I, Geologia: 72-82.

Majewski, A., 1986. Extreme water level fluctuations along the Baltic coast (in Polish with English summary). Inżynieria Morska, 2 : 46-50.

Majewski, A., 1989. Unusually short-lived sea water level oscillations on the southern and eastern coasts of the Baltic Sea (in Polish with English summary). Przegląd Geofizyczny, 34: 191-199.

Majewski, A., 1998a. The highest storm surges along the southern coast of the Baltic Sea (in Polish with English summary).
Wiadomości Instytutu Meteorologii i Gospodarki Wodnej, 21: $81-98$

Majewski, A., 1998b. Disastrous storms and floods on southern coasts of the Baltic Sea (in Polish with English summary). Inżynieria Morska i Geotechnika, 2: 67-69.

Matsumoto, D., Sawai, Y., Yamada, M., Namegaya, Y., Shinozaki, T., Takeda, D., Fujino, S., Tanigawa, K., Nakamura, A., Pilarczyk, J.E., 2016. Erosion and sedimentation during the September 2015 flooding of the Kinu River, central Japan. Scientific Reports, 6, Article number: 34168. doi:10.1038/srep34168

Medvedev, I.P., Rabinovich, A.B., Kulikov, E.A., 2013. Tidal oscillations in the Baltic Sea. Oceanology, 53: 526-538.

Mörner, N.A., 1995. The Baltic Ice Lake - Yoldia Sea transition. Quaternary International, 27: 95-98.

Mörner, N.A., 1996. Liquefaction and varve disturbance as evidence of paleoseismic events and tsunamis, the autumn $10430 \mathrm{BP}$ event in Sweden. Quaternary Science Reviews, 15: 939-948.

Mörner, N.A., 1999. Paleo-tsunamis in Sweden. Physics and Chemistry of the Earth, 24: 443-448.

Mörner, N.A., 2003. Paleoseismity of Sweden - a Novel Paradigm. Stockholm University, Stockholm.

Mörner, N.A., 2008. Tsunami events within the Baltic. Polish Geological Special Papers, 23: 71-76.

Mörner, N.A., 2013. Drainage varves, seismites and tsunamites in the Swedish varve chronology. GFF, 135: 308-315.

Mörner, N.A., Dawson, S., 2011. Traces of tsunami events in offand on-shore environments. Case studies in the Maldives, Scotland and Sweden. In: The Tsunami Threat - Research and Technology (ed. N.A. Mörner): 371-388. InTech.

Morton, R.A., Sallenger, A.H. Jr., 2003. Morphological impacts of extreme storms on sandy beaches and barriers. Journal of Coastal Research, 19: 560-573.

Morton, R.A., Gelfenbaum, G., Jaffe, B.E., 2007. Physical criteria for distinguishing sandy tsunami and storm deposits using modern examples. Sedimentary Geology, 200: 184-207.

Nanayama, F., Shigeno, K., Satake, K., Shimokawa, K., Koitabashi, S., Miyasaka, S., Ishii, M., 2000. Sedimentary differences between the 1993 Hokkaido-nansei-oki tsunami and the 959 Miyakojima typhoon at Taisei, southwestern Hokkaido, northern Japan. Sedimentary Geology, 135: 255-264.

Nikonov, A.A., 2004. Evidence of paleotsunami in the early Holocene Lake Kunda (southern coast of the Gulf of Finland). Doklady Earth Sciences, 396: 477-480.

Pellikka, H., Rauhala, J., Kahma, K.K., Stipa, T., Boman, H., Kangas, A., 2014. Recent observations of meteotsunamis on the Finnish coast. Natural Hazards, 74: 197-215.

Peters, R., Jaffe, B., 2010. Identification of Tsunami Deposits in the Geologic Record: Developing Criteria Using Recent Tsunami Deposits. US Geological Survey Open-File Report: 2010-1239.

Piotrowski, A., 2007a. Tsunami events in Kołobrzeg in the light of historical evidences. Biuletyn Państwowego Instytutu Geologicznego, 424: 73.

Piotrowski, A., 2007b. Tsunami AD 1497. Biuletyn Państwowego Instytutu Geologicznego, 424: 77.

Reimer, P.J., Bard, E., Bayliss, A., Warren Beck, J., Blackwell, P.G., Bronk Ramsey, C., Buck, C.E., Cheng, H., Edwards, R.L., Friedriech, M., Grootes, P.M., Giuilderson, T.P., Hafilidason, H., Hajdas, I., Hatte, C., Heaton, T.J., Hoffman, D.L., Hogg, A.G., Hughen, A.G., Kaiser, A.K., Kromer, B., Manning, S.W., Niu, M., Reimer, R.W., Richards, D.A., Scott, E.M., Sothon, J.R., Staff, R.A., Turney, C.S.M., van der Plicht, J., 2013. INTCAL13 and Marine13 radiocarbon age calibration curves 0-50 000 years cal BP. Radiocarbon, 55: 1869-1887.

Richmond, B., Szczuciński, W., Chagué-Goff, C., Goto, K., Sugawara, D., Witter, R., Tappin, D.R., Jaffe, B., Fujino, S., Nishimura, Y., Goff, J., 2012. Erosion, deposition and landscape change on the Sendai coastal plain, Japan, resulting from the March 11, 2011 Tohoku-oki tsunami. Sedimentary Geology, 282: 27-39.

Richter, A., Groh, A., Dietrich, R., 2012. Geodetic observation of sea-level change and crustal deformation in the Baltic Sea region. Physics and Chemistry of the Earth Pt., A/B/C: 43-54. 
Riemann, H., 1873. Geschichte der Stadt Kolberg. Karl Jancke Verlag.

Rosenhagen, G., Bork, I., 2009. Rekonstruktion der Sturmflutwetterlage vom 13. November 1872. Die Küste, 75: 51-70.

Rotnicki, K., Rotnicka, J., Goslar, T., Wawrzynniak-Wydrowska, B., 2016. The first geological record of a palaeotsunami on the southern coast of the Baltic Sea, Poland. Geological Quarterly, 60 (2): 417-440.

Rudowski, S., Wróblewski, R., 2000. Sedimentary structure of the storm surge washover fan on the Lake Bukowo spit. Oceanological Studies, 29: 101-107.

Shiki, T., Tachibana, T., Fujiwara, O., Goto, K., Nanayama, F., Yamazaki, T., 2008. Characteristic features of tsunamiites. In: Tsunamiites - Features and Implications (eds. T. Shiki, Y. Tsuji, T. Yamasaki and K. Minoura): 319-340, Elsevier.

Skolasińska, K., Szczuciński, W., Mitręga, M., Jagodziński, R., Lorenc, S., 2015. Sedimentary record of 2010 and 2011 Warta River seasonal floods in the region of Poznań, Poland. Geological Quarterly, 59 (1): 47-60.

Soria, J.L.A., Switzer, A.D., Pilarczyk, J.E., Siringan, F.P., Khan, N.S., Fritz, H.M., 2017. Typhoon Haiyan overwash sediments from Leyte Gulf coastlines show local spatial variations with hybrid storm and tsunami signatures. Sedimentary Geology, 358: 121-138.

Starkel, L., Michczyńska, D., Krąpiec, M., Margielewski, W., Nalepka, D., Pazdur, A., 2013. Progress in the Holocene chrono-climatostratigraphy of Polish territory. Geochronometria, 40: 1-21.

Stigge, H.J., 1994. Die Wasserstande an der Küste Mecklenburg-Vorpommern. Die Küste, 56: 1-24.

Stoewer, R., 1897. Geschichte der Stadt Kolberg. C. F. Post'schen Buchhandlung und Buchdruckerei.

Stuiver, M., Reimer, P.J., Reimer, R.W., 2016. CALIB 7.1 (WWW program) at http://calib.org, accessed 2016-12-2

Suursaar, U., Kullas, T., Otsmann, M., Kouts, T., 2003. Extreme sea level events in the coastal waters of western Estonia. Journal of Sea Research, 49: 295-303.

Suursaar, U., Kullas, T., Otsmann, M., Saaremae, I., Kuik, J., Merilain, M., 2006. Cyclone Gudrun in January 2005 and modeling its hydrodynamic consequences in the Estonian coastal waters. Boreal Environment Research, 11: 143-159.

Switzer, A.D., 2008. 20 years of paleotsunami studies on coastal sandsheets - a review. 2nd International Tsunami Field Symposium. IGCP Project 495. GI2S Coast Research Publication, 6: 163-165.
Switzer, A.D., Jones, B.G., 2008. Large-scale washover sedimentation in a freshwater lagoon from the southeast Australian coast: sea-level change, tsunami or exceptionally large storm? The Holocene, 18: 787-803.

Szczuciński, W., 2012. The post-depositional changes of the onshore 2004 tsunami deposits on the Andaman Sea coast of Thailand. Natural Hazards, 60: 115-133.

Szczuciński, W., Kokociński, M., Rzeszewski, M., Chagué-Goff, C., Cachao, M., Goto, K., Sugawara, D., 2012a. Sediment sources and sedimentation processes of 2011 Tohoku-oki tsunami deposits on the Sendai Plain, Japan - insights from diatoms, nannoliths and grain size distribution. Sedimentary Geology, 282: 40-56.

Szczuciński, W., Rachlewicz, G., Chaimanee, N., Saisuttichai, D., Tepsuwan, T., Lorenc, S., 2012b. 26 December 2004 tsunami deposits left in areas of various tsunami runup in coastal zone of Thailand. Earth, Planets and Space, 64: 843-858.

Szczuciński, W., Pawłowska, J., Lejzerowicz, F., Nishimura, Y., Kokociński, M., Majewski, W., Nakamura, Y., Pawlowski, J., 2016. Ancient sedimentary DNA reveals past tsunami deposits. Marine Geology, 381: 29-33.

Tappin, D.R., Evans, H., Jordan, C.J., Richmond, B., 2012. Coastal changes from the impact of the 2011 Tõhoku-oki tsunami: interpretations of time series satellite images, helicopter-borne video footage and field observations. Sedimentary Geology, 282: 151-174.

Tuttle, M.P., Ruffman, A., Anderson, T., Jeter, H., 2004. Distinguishing tsunami from storm deposits in eastern North America: the 1929 Grand Banks tsunami versus the 1991 Halloween storm. Seismological Research Letters, 75: 117-131.

Van Dam, H., Mertens, A., Sineldam, J., 1994. A coded checklist and ecological indicator values of freshwater diatom from the Netherlands. Netherlands Journal of Aquatic Ecology, 28: 117-133.

Williams, H.F.L., 2015. Contrasting styles of Hurricane Irene washover sedimentation on three east coast barrier islands: Cape Lookout, North Carolina; Assateague Island, Virginia; and Fire Island, New York. Geomorphology, 231: 182-192.

Wiśniewski, B., Wolski, T., 2009. Katalogi wezbrań i obniżeń sztormowych poziomów morza oraz ekstremalne poziomy wód na polskim wybrzeżu (in Polish). Wydawnictwo Naukowe Akademii Morskiej, Szczecin.

Wolski, T., Wiśniewski, B., Giza, A., Kowalewska-Kalkowska, H., Boman, H., Grabbi-Kaiv, S., Hammarklint, T., Holfort, J., Lydeikaite, Z., 2014. Extreme sea levels at selected stations on the Baltic Sea coast. Oceanologia, 56: 259-290. 